Original Article

\title{
Mechanistic and phenotypic studies of bicarinalin, BP100 and colistin action on Acinetobacter baumannii
}

\author{
Marcus G. Eales ${ }^{\mathrm{a}, \mathrm{b}}$, Enrico Ferrari ${ }^{\mathrm{a}}$, Alan D. Goddard ${ }^{\mathrm{a}, \mathrm{c}}$, Lorna Lancaster ${ }^{\mathrm{a}}$, Peter Sanderson ${ }^{\mathrm{a}, \mathrm{d}}$, Clare Miller ${ }^{\mathrm{a}, \text { * }}$ \\ ${ }^{a}$ University of Lincoln, Joseph Banks Laboratories, Lincoln, LN6 7DL, UK \\ ${ }^{\mathrm{b}}$ University of Bristol, School of Oral and Dental Sciences, Bristol, BS8 1TH, UK \\ ${ }^{c}$ Aston University, School of Life and Health Sciences, Birmingham, B4 7ET, UK \\ ${ }^{\mathrm{d}}$ University of Sheffield, Dept. of Chemistry, Sheffield, S3 7HF, UK
}

\section{A R T I C L E I N F O}

Article history:

Received 24 November 2017

Accepted 20 April 2018

Available online $\mathrm{xxx}$

\section{Keywords:}

Scanning electron microscopy

Atomic force microscopy

Vesicle leakage

Biofilm

Antimicrobial peptides

Antibiotic resistance

\section{A B S T R A C T}

Acinetobacter baumannii has been identified by the WHO as a high priority pathogen. It can be resistant to multiple antibiotics and colistin sulphate is often used as a last-resort treatment. However, the potentially severe side-effects of colistin are well documented and this study compared the bactericidal and anti-biofilm activity of two synthetic nature-inspired antimicrobial peptides, bicarinalin and BP100, with colistin. The minimum bactericidal concentration (MBC) against planktonic A. baumannii was approximately $0.5 \mu \mathrm{g} / \mathrm{ml}$ for colistin sulphate and $\sim 4 \mu \mathrm{g} / \mathrm{ml}$ for bicarinalin and BP100. A. baumannii commonly occurs as a biofilm and biofilm removal assay results highlighted that both bicarinalin and BP100 had significantly greater potential than colistin. Atomic force microscopy (AFM) showed dramatic changes in A. baumannii cell size and surface conformity when treated with peptide concentrations at and above the MBC. Scanning electron microscopy (SEM) visualised the reduction of biofilm coverage and cell surface changes as peptide concentration increased. Liposome assays revealed that these peptides most likely act as pore-forming agents in the membrane. Bicarinalin and BP100 may be effective therapeutic alternatives to colistin against $A$. baumannii infections but further research is required to assess if they elicit cytotoxicity issues in patients.

(C) 2018

\section{Introduction}

It has been widely publicised that by 2050 , deaths due to antimicrobial resistant (AMR) infections may rise to 10 million per year and during that time, 300 million people will die from AMR infections [1]. The abuse of currently used antimicrobials, the paucity of new antimicrobials progressing successfully through clinical trials and the evolution of bacterial resistance mechanisms have led to the prospect of returning to the pre-antibiotic era when patients were dying from infections through minor injuries and routine surgeries. Although the recent development of novel antibiotics [2,3] has provided reason for optimism, these drugs are generally limited to the treatment of Gram-positive infections while Gram-negative pathogens remain of significant concern [4].

Acinetobacter baumannii is one such opportunistic pathogen $[5,6]$ occurring almost exclusively in the hospital environment and is particularly prevalent in intensive care and burns units; it has been reported to be responsible for between 2 and $10 \%$ of all Gram-negative nosocomial infections [7]. A member of the 'ESKAPE' group [8] of

\footnotetext{
* Corresponding author.

Email addresses: marcus.eales@bristol.ac.uk (M.G. Eales); eferrari@lincoln.ac. uk (E. Ferrari); a.goddard@aston.ac.uk (A.D. Goddard); llancaster@lincoln.ac.uk (L. Lancaster); p.sanderson@sheffield.ac.uk (P. Sanderson); cmiller@lincoln.ac. uk (C. Miller)
}

pathogens, A. baumannii is able to persist on clinical surfaces by forming biofilms [7,9], an ability that renders bacteria more resistant to many common antimicrobials $[10,11]$ leading to A. baumannii infections becoming rapidly more difficult to treat [12]. It is able to persist for long periods on fomites [7,9] enabling the pathogen to cause widespread epidemic infections in nosocomial settings. Current treatments include $\beta$-lactam antibiotics with the carbapenems typically the treatment of choice [9].

Antimicrobial peptides (AMPs) have been much heralded as alternatives to antibiotics due to their ability to destroy multi-drug resistant (MDR) bacteria [13]. One example is colistin sulphate (colistin), commonly used as a last resort treatment for MDR A. baumannii infections [14]. However, the toxicity of colistin in patients is well known $[13,14]$ and resistance is increasingly described [15-17] resulting in a crucial search for improved alternatives.

The aim of this study was to establish and visualise the activity of two little researched AMPs, bicarinalin and BP100, which may be appropriate for use instead of colistin to treat MDR A. baumannii infections. Bicarinalin is an amphipathic, C-terminally amidated, novel antimicrobial peptide derived from the venom of the myrmicine ant, Tetramorium bicarinatum [18,19]. It consists of a sequence of 20 amino acid residues (KIKIPWGKVKDFLVGGMKAV) with a molecular weight of $2213.78 \mathrm{~g} / \mathrm{mol}$. The action of bicarinalin has been evaluated against a selection of Gram-positive and Gram-negative or- 
ganisms $[18,19]$ and has been found to have good antibacterial activity compared to other AMPs together with less haemolytic activity.

BP100 is a short C-amidated undecapeptide consisting of 11 amino acids (KKLFKKILKYL) and a molecular weight of $1420.88 \mathrm{~g} / \mathrm{mol}$. It was originally synthesised by combinatorial chemistry involving two peptides, cecropin A and melittin [20]. Cecropin A is a member of the well-researched AMP family, the cecropins, first isolated from the giant silk moth Hyalophora cecropia. The cecropin family, although susceptible to protease degradation, does not exhibit cytotoxic effects against human erythrocytes [21,22]. Melittin is a 26 amino acid, haemolytic alpha helical peptide first purified from the European honeybee in 1958 [23], with demonstrated antibacterial activity [24]. However, on its own, melittin's strong cytotoxic action makes it unsuitable for clinical applications [25]. To circumvent cecropin A's susceptibility to proteolytic degradation and melittin's high cytotoxicity, they were combined to produce a derivative, BP100. BP100 exhibits low susceptibility to protease degradation and lower cytotoxicity against erythrocytes and fibroblasts [26]. BP100 has been established to have good antibacterial activity against several Gram-negative bacteria $[20,22]$.

It is believed that bicarinalin's antibacterial mechanism is similar to other AMPs, with its cationic charge, as a result of lysine residues, naturally attracted to the anionic charged bacterial cell surface. It is also believed that BP100 interacts with the bacterial cell membrane via electrostatic attraction to the negatively charged LPS layer, causing blebbing on the surface leading to a collapse of the outer membrane [20].

The aim of this study was to assess the potential of bicarinalin and BP100 as alternatives to colistin to treat A. baumannii infections. The study also aimed to visualise the effects of these antimicrobial agents on A. baumannii cells and biofilms using scanning electron microscopy (SEM) and atomic force microscopy (AFM).

\section{Materials and methods}

\subsection{Bacterial culture conditions}

Fresh cultures of $A$. baumannii $\left(\right.$ ATCC $^{\circledR}$ 19,606) were prepared by streaking a culti-loop (ThermoFisher Scientific, UK) on freshly prepared Tryptone Soya Agar (TSA, Oxoid, UK) and incubated for $24 \mathrm{~h}$ at $37^{\circ} \mathrm{C}$. Purity was assessed using Gram staining, cell morphology, oxidase and Analytical Profile Index (API, Biomérieux, UK, 20NE kit) testing. A standard growth curve for the A. baumannii was established to ensure mid-log phase growth and an initial inoculum of $5 \times 10^{5} \mathrm{CFU} / \mathrm{ml}$ at the start of each experiment.

\subsection{Antimicrobial assays}

\subsubsection{Minimum inhibitory concentration (MIC)}

The MIC was determined for each of the antimicrobial agents studied: colistin (Sigma-Aldrich, UK), bicarinalin (97.7\% purity, Genscript, USA) and BP100 (98.4\% purity, Genscript, USA). $10 \mathrm{ml}$ of sterile Tryptone Soya Broth (TSB, Oxoid, UK) was inoculated with 2-3 colonies of $A$. baumannii and incubated overnight at $37^{\circ} \mathrm{C}$ and later diluted to an absorbance that equated to $1 \times 10^{6} \mathrm{CFU} / \mathrm{ml}$.

Antimicrobial solutions were prepared and sterilised by filtering through a $0.2 \mu \mathrm{m}$ minisart single use sterile filter (Sartorius-Stedim Biotech, Fisherscientific, UK). Stock solutions (1024 $\mu \mathrm{g} / \mathrm{ml})$ were prepared, taking into account the stated product purity. Reduction of peptide concentration through filtration was not assayed for.

$50 \mu \mathrm{l}$ of each agent, at a stock concentration of $1024 \mu \mathrm{g} / \mathrm{ml}$, was added to well 1 of a 96-well microplate (Fisherscientific, UK) and a two-fold dilution series prepared in wells 2 to $12.50 \mu \mathrm{l}$ of inoculated TSB, containing $1 \times 10^{6} \mathrm{CFU} / \mathrm{ml}$ of $A$. baumannii, was then added to each well resulting in final peptide concentrations from $256 \mu \mathrm{g} / \mathrm{ml}$ to $0.125 \mu \mathrm{g} / \mathrm{ml}$ and a cell density of $5 \times 10^{5} \mathrm{CFU} / \mathrm{ml}$. Plates were covered and incubated in a shaking incubator at $37^{\circ} \mathrm{C}$ and $140 \mathrm{rpm}$ for $24 \mathrm{~h}$. The lowest concentration of peptide where the well was visibly clear was recorded as the MIC. The entire experiment was carried out three times in triplicate to give nine datasets and the mean MIC established.

\subsubsection{Minimum bactericidal concentration $(M B C)$}

After recording the MIC, spread plates were prepared on TSA using $100 \mu \mathrm{l}$ from each clear well. These plates were incubated at $37^{\circ} \mathrm{C}$ for $24 \mathrm{~h}$. The lowest concentration where there was no growth observed on the plate was recorded as the MBC. This was carried out after each MIC test and therefore three times in triplicate.

\subsubsection{Minimum biofilm inhibitory concentration (MBIC)}

A 96-well microplate plate containing doubling dilutions of antimicrobial was incubated with $5 \times 10^{5} \mathrm{CFU} / \mathrm{ml}$ A. baumannii for $24 \mathrm{~h}$ at $37^{\circ} \mathrm{C}, 140 \mathrm{rpm}$. After $24 \mathrm{~h}$, the wells were emptied and washed three times with $1 / 4$ strength Ringer's solution and air dried for $1 \mathrm{~h} .1 \%$ crystal violet solution was added to each well and left at room temperature for $10 \mathrm{~min}$. The wells were emptied by pipetting, washed three times with distilled water, and air dried for $30 \mathrm{~min}$ at $37^{\circ} \mathrm{C}$. The stain was solubilised with $96 \%$ ethanol $(100 \mu \mathrm{l})$. The plate was covered and shaken at $140 \mathrm{rpm}$ for $30 \mathrm{~min} 2 \mu \mathrm{l}$ was removed and the absorbance of the solution was measured at $590 \mathrm{~nm}$ compared to a $96 \%$ ethanol blank. This was replicated three times and the mean calculated. The percentage biofilm inhibited was calculated by comparing against an untreated bacterial control. SPSS Statistics 21 (IBM, USA) was used for the statistical analysis of MBIC results. The samples t-test was used to find if there was a statistical difference of $95 \%(p \leq 0.05$, statistically significant) or $99 \%$ ( $\mathrm{p} \leq 0.01$, highly significant).

\subsection{Biofilm removal assay}

Biofilms of $A$. baumannii were grown in 36 wells of a 96-well microplate (test plate) by adding $50 \mu 1$ sterile TSB and $50 \mu \mathrm{l}$ of TSB inoculated with $1 \times 10^{6} \mathrm{CFU} / \mathrm{ml}$ culture. Plates were incubated at $37^{\circ} \mathrm{C}$, $140 \mathrm{rpm}$ for $24 \mathrm{~h}$. On a separate 96-well microplate (titration plate) a doubling dilution series was prepared with $75 \mu \mathrm{l}$ of TSB and $75 \mu \mathrm{l}$ of antimicrobial solution (stock concentration, $8192 \mu \mathrm{g} / \mathrm{ml}$ ). The wells containing biofilm were washed three times with $1 / 4$ strength Ringer's solution and $75 \mu \mathrm{l}$ sterile TSB was then added to each well. $75 \mu \mathrm{l}$ from the titration plate, containing a specific concentration of peptide, was added to the corresponding well on the test plate. This resulted in each well containing $150 \mu \mathrm{l}$ of TSB, which ensured the biofilm was completely submerged, and the test wells containing a doubling dilution series of antimicrobial $(2048 \mu \mathrm{g} / \mathrm{ml}$ to $2 \mu \mathrm{g} / \mathrm{ml})$. $150 \mu \mathrm{l}$ sterile TSB was added to the negative control wells. Plates were covered and incubated in a shaking incubator for $24 \mathrm{~h}$ at $37{ }^{\circ} \mathrm{C}, 140 \mathrm{rpm}$. After incubation, the wells were emptied by tipping onto absorbent paper, washed three times with $200 \mu 1$ 1/4 strength Ringer's solution and air fixed for $1 \mathrm{~h}$ under aseptic conditions.

The percentage of biofilm removal was quantified by measuring the absorbance after applying crystal violet stain as described previously. The absorbance (at $590 \mathrm{~nm}$ ) was determined for each sample. Biofilm reduction (\%) was determined by comparison of the absorbance readings of the samples with the untreated control biofilms. 
SPSS Statistics 21 software (IBM, USA) was used to assess the significance of the biofilm removal assay results. The samples t-test was applied to assess the statistical difference of $95 \%(\mathrm{p} \leq 0.05)$ which was considered as statistically significant or $99 \%(\mathrm{p} \leq 0.01)$ which was considered highly significant.

\subsection{Scanning electron microscopy}

A. baumannii biofilms were prepared in $150 \mu \mathrm{TSB}$ in 96-well microplates. Calgary Biofilm Device (CBD) lids (Nunc-TSP Screening Plate Lids, ThermoScientific, UK) were placed on the plates with the polystyrene pegs protruding into the broth. Plates were sealed and incubated at $37^{\circ} \mathrm{C}, 140 \mathrm{rpm}$ for $24 \mathrm{~h}$. After incubation, the pegs were washed by submerging in $200 \mu$ of sterile $1 / 4$ strength Ringer's solution and leaving for $2 \mathrm{~min}$ and this process was repeated twice more. Each well was then filled with $100 \mu$ l sterile TSB.

Antimicrobial challenge plates were prepared, containing agent concentrations of $1 \mu \mathrm{g} / \mathrm{ml}, 10 \mu \mathrm{g} / \mathrm{ml}$ and $100 \mu \mathrm{g} / \mathrm{ml}$. The CBD lid was placed onto this challenge plate, covered and incubated at $37^{\circ} \mathrm{C}$, $140 \mathrm{rpm}$ for $24 \mathrm{~h}$. After $24 \mathrm{~h}$ the pegs were washed by submerging the $\mathrm{CBD}$ lid in $250 \mu \mathrm{l}$ of sterile $1 / 4$ strength Ringer's solution and leaving for $2 \mathrm{~min}$ and subsequently repeated twice more.

$0.1 \mathrm{M}$ sodium cacodylate buffer was prepared to give a $\mathrm{pH}$ reading of 7.2. The CBD pegs were then submerged in this solution for $3 \mathrm{~min}$.

$2.5 \%$ glutaraldehyde solution was prepared. The CBD lid was immersed in the buffer, covered and left at ambient temperature $\left(21 \pm 2{ }^{\circ} \mathrm{C}\right)$ for $40 \mathrm{~min}$. The CBD lid was then removed and twice washed in distilled water for $2 \mathrm{~min}$. Biofilms were then dehydrated sequentially by placing twice into $50 \%$ methanol (Fisher Scientific, UK), $70 \%$ methanol and finally $100 \%$ methanol. CBD lids were left in each solution for $2 \mathrm{~min}$. Pegs were subsequently air dried for 4 days.

Pegs were removed from the CBD lid and mounted onto 0.5" aluminium specimen stubs, fixed using carbon adhesive discs (Agar Scientific, UK). After mounting, the carbon tabs were painted with graphite and the pegs were coated with approximately $15-20 \mathrm{~nm}$ of platinum. A. baumannii biofilms on the surface of the pegs were visualised using a FEI Quanta FEG 650 Scanning Electron Microscope.

\subsection{Vesicle leakage assays}

Liposomes were made from lipids extracted from A. baumannii. A. baumannii cultured at $37^{\circ} \mathrm{C}$ was harvested and a total lipid extraction conducted as described by Bligh \& Dyer [27], with an extra step to extract any lipid remaining in the supernatant plus $3 \times$ washing steps with $1 \mathrm{M} \mathrm{KCl}$. The extracted lipid was stored in chloroform at $-20^{\circ} \mathrm{C}$. A Stewart lipid assay was conducted to quantify the lipid extracted.

$2 \mathrm{mg}$ lipid, dried from chloroform in a round-bottomed flask, was hydrated in $1 \mathrm{ml} 100 \mathrm{mM} 5$ (6)-carboxyfluorescein (Sigma Aldrich, UK) and allowed to hydrate for $25 \mathrm{~min}$ with occasional shaking. The resulting suspension was extruded through a $400 \mathrm{~nm}$ filter and then a $100 \mathrm{~nm}$ Nuclepore track-etched polycarbonate membrane (Whatman, UK) using a mini-extruder (Avanti Polar Lipids, USA) at $37^{\circ} \mathrm{C}$. The extruded liposomes were then washed 3 times to remove un-encapsulated carboxyfluorescein by pelleting at 100,000 $\mathrm{g}$ and re-suspending in $50 \mathrm{mM}$ Tris- $\mathrm{HCl}$ buffer and $10 \mathrm{mM} \mathrm{NaCl}$ at $\mathrm{pH} 7.3$ before final re-suspension in $1 \mathrm{ml}$ of the same buffer.

$6.25 \mu \mathrm{l}$ of the above liposome suspension was added to $500 \mu \mathrm{l}$ aliquots of antimicrobial peptide solutions at the following concentrations: $0.25,0.5,1,2,4,8,16,32,64,128,256 \& 512 \mu \mathrm{g} / \mathrm{ml}$ in the above Tris buffer. An additional concentration of $0.125 \mu \mathrm{g} / \mathrm{ml}$ was used for colistin due to its lower MIC. $100 \mu \mathrm{l}$ aliquots were transferred to black 96-well microplates for fluorescence measurements at $490 \mathrm{~nm}$ excitation and $520 \mathrm{~nm}$ emission using an Infinite 200Pro (Tecan, Switzerland). Carboxyfluorescein leakage was measured relative to the same quantity of liposomes suspended in 1\% SDS following approximately $30 \mathrm{~min}$ exposure to the agent.

\section{Results}

\subsection{Antimicrobial assays}

MIC and MBC values were determined to be $0.5 \mu \mathrm{g} / \mathrm{ml}$ $(0.43 \mu \mathrm{mol} / \mathrm{L})$ for colistin, $4 \mu \mathrm{g} / \mathrm{ml}(1.8 \mu \mathrm{mol} / \mathrm{L})$ for bicarinalin and $4 \mu \mathrm{g} / \mathrm{ml}(2.8 \mu \mathrm{mol} / \mathrm{L})$ for BP100 (data not shown). Fig. 1 shows that the MBIC was found to be similar to the MIC and MBC for each agent with $90 \%$ of biofilm formation inhibited at $0.5 \mu \mathrm{g} / \mathrm{ml}$ colistin

\subsection{Atomic force microscopy}

Atomic force microscopy (AFM) was used to obtain topographic images of $A$. baumannii cells when subjected to peptide concentrations equating to $1 / 2 \mathrm{MBC}, \mathrm{MBC}$ and $2 \times \mathrm{MBC}$. These concentrations were $0.25,0.5$ and $1 \mu \mathrm{g} / \mathrm{ml}$ for colistin and 2,4 and $8 \mu \mathrm{g} / \mathrm{ml}$ for both bicarinalin and BP100. $150 \mu \mathrm{l}$ suspensions, containing inoculated TSB with $A$. baumannii cell density of $5 \times 10^{5} \mathrm{CFU} / \mathrm{ml}$ and appropriate concentrations of antimicrobial, were prepared in 96-well microplates. Plates were incubated at $37{ }^{\circ} \mathrm{C}, 140 \mathrm{rpm}$ for $2 \mathrm{~h}$.

After incubation the suspension was pipetted onto a poly-L-lysine coated slide (Sigma Aldrich, UK) and left at ambient room temperature $\left(21 \pm 2^{\circ} \mathrm{C}\right)$ for $20 \mathrm{~min}$. Slides were rinsed with distilled water and left to air dry.

Images were captured using a Bioscope Catalyst AFM (Bruker, Germany) operated in PeakForce tapping mode using ScanAsyst-air tips (Bruker, Germany). Images were acquired on an area of $4 \mu \mathrm{m}^{2}$ at a scan rate of $0.5 \mathrm{~Hz}$.

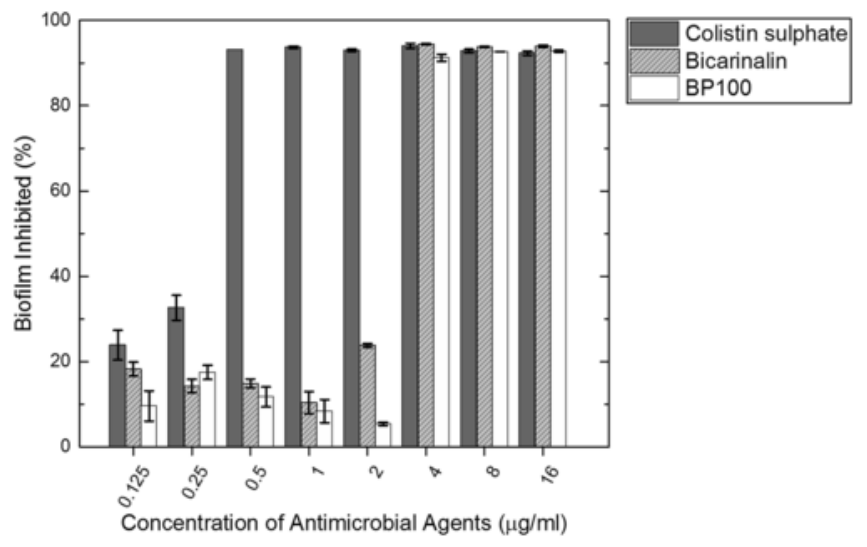

Fig. 1. MBIC for colistin sulphate, bicarinalin and BP100. A. baumannii was subjected to a doubling dilution series $(2-2048 \mu \mathrm{g} / \mathrm{ml})$ of antimicrobial for $24 \mathrm{~h}$. After washing and air fixing for $1 \mathrm{~h}$, samples were stained with $1 \%$ crystal violet. After $10 \mathrm{~min}$ the stain was solubilised with $96 \%$ ethanol and the absorbance at $590 \mathrm{~nm}$ was read against a $96 \%$ ethanol blank. The percentage biofilm inhibited was calculated by comparing against an untreated bacterial control. The experiment was carried out three times in triplicate. 
and $4 \mu \mathrm{g} / \mathrm{ml}$ bicarinalin and BP100. This also showed that at concentrations below the peptides' respective MBCs, biofilm formation was possible with only $36 \%$ biofilm inhibition for colistin, $23 \%$ for bicarinalin and $20 \%$ for BP100. Fig. 2 shows the eradication of a 24-h biofilm when subjected to increasing concentrations of peptide. At $1 \mu \mathrm{g} / \mathrm{ml}$ of colistin, $27 \%$ of biofilm was removed. As the peptide concentration increased, more biofilm was eradicated with $52 \%$ removed at $512 \mu \mathrm{g} / \mathrm{ml}$. Bicarinalin removed $18 \%$ at $1 \mu \mathrm{g} / \mathrm{ml}$ which then increased to $70 \%$ at $128 \mu \mathrm{g} / \mathrm{ml}$; no further biofilm eradication was observed with higher concentrations. BP100 removed $17 \%$ at $1 \mu \mathrm{g} /$ $\mathrm{ml}$ which remained low until $16 \mu \mathrm{g} / \mathrm{ml}$. Above this concentration, the biofilm removed increased from $27 \%$ at $32 \mu \mathrm{g} / \mathrm{ml}$ to $76 \%$ at $512 \mu \mathrm{g} /$ $\mathrm{ml}$, higher than both colistin and bicarinalin, to $93 \%$ at $2048 \mu \mathrm{g} / \mathrm{ml}$.

\subsection{Microscopy}

SEM (Fig. 3) and AFM (Fig. 4) provide visualisation of the effects of these agents on A. baumannii cells. Fig. 3 demonstrates that, as the concentration of the agents increases, the morphological changes to the cells become more pronounced including evidence of blebbing and a more variable cell shape with shrinkage and membrane disruption. The coverage across the surface also reduces: with no addition of antimicrobial agent the cells are packed closely together and cover the whole interface; as the peptide concentration increases visible gaps are seen between clusters of cells. The cellular morphological changes are also observed in Fig. 4 by AFM. Blebbing is observed, causing varied cell shape and shrinkage at the MBC concentrations, and the cells differ greatly compared to the cocci-bacilli shaped cells seen with no antimicrobial treatment and below the MBC.

\subsection{Vesicle leakage assays}

To determine the mechanism of action of the antimicrobial agents, a vesicle leakage assay was performed. Liposomes produced from lipids extracted from A. baumannii (Fig. 5) all leaked carboxyfluorescein in the presence of the antimicrobials. The concentration of agent causing half-maximal leakage for each agent was $\sim 1.75 \mu \mathrm{g} / \mathrm{ml}$ for colistin, $\sim 2.75 \mu \mathrm{g} / \mathrm{ml}$ for BP100 and $\sim 2 \mu \mathrm{g} / \mathrm{ml}$ for bicarinalin (given maximal leakage of $70 \%, 65 \%$ and $56 \%$ respectively). Vesicle leak-

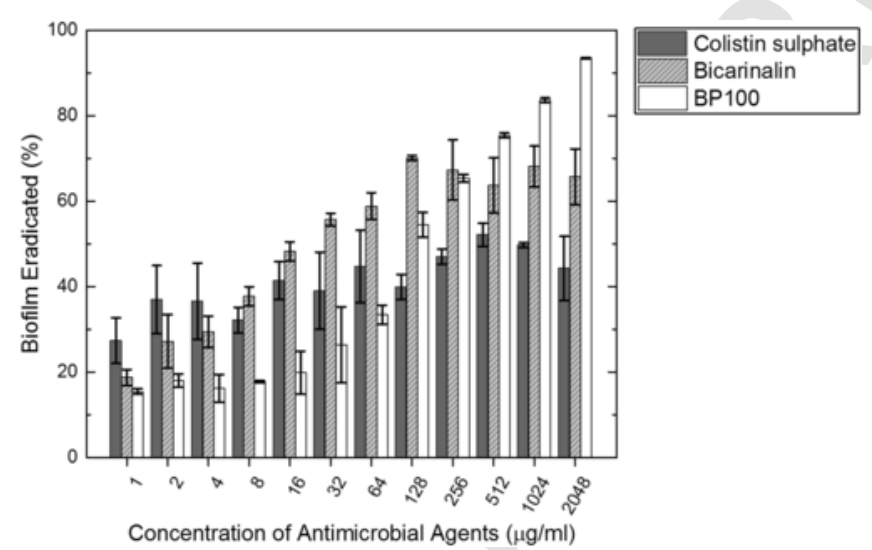

Fig. 2. Percentage biofilm eradication by colistin sulphate, bicarinalin and BP100. A. baumannii biofilms were grown for $24 \mathrm{~h}$ and then subjected to a doubling dilution series $(2-2048 \mu \mathrm{g} / \mathrm{ml})$ of antimicrobial for $24 \mathrm{~h}$. After washing and air fixing for $1 \mathrm{~h}$, samples were stained with $1 \%$ crystal violet. After 10 min the stain was solubilised with $96 \%$ ethanol and the absorbance at $590 \mathrm{~nm}$ was read against a $96 \%$ ethanol blank. The percentage biofilm eradicated was calculated by comparing against an untreated bacterial control. The experiment was carried out twice in triplicate. age results support the proposal that these agents exert effects on the bacterial cell membrane causing significant disruption to the cell surface (as shown in Fig. 4) and eventually cell lysis (as shown in Fig. 3).

\section{Discussion}

A. baumannii susceptibility to colistin was similar to that determined by Li et al. [28] and Sauger [29], confirming that A. baumannii 19,606 strain is colistin susceptible as defined by The Clinical and Laboratory Standards Institute. Bicarinalin results were compared with those of Rifflet [18] and Téné [19] who investigated Cronobacter spp., Enterobacter spp. and Staphylococcus spp., Results suggest that $A$. baumannii is generally more susceptible to bicarinalin than these other bacteria. Antimicrobial activity results for BP100 against $\mathrm{A}$. baumannii 19,606 were comparable to other bacteria in previous studies $[20,21]$.

Although the MBC for both bicarinalin and BP100 was $4 \mu \mathrm{g} / \mathrm{ml}$, the molar concentration of peptide differed $(1.8 \mu \mathrm{mol} / \mathrm{L}$ for bicarinalin and $2.8 \mu \mathrm{mol} / \mathrm{L}$ for BP100). This is primarily due to the differences in molecular weight (bicarinalin $2213.78 \mathrm{~g} / \mathrm{mol}$, BP100 $1420.88 \mathrm{~g} / \mathrm{mol}$ ) indicating that, although BP100 is smaller in length, it exerts a similar inhibitory and potent effect on A. baumannii. By comparison, colistin has a $\mathrm{MBC}$ of $0.43 \mu \mathrm{mol} / \mathrm{L}$ (with the smallest molecular weight, $1155.4 \mathrm{~g} / \mathrm{mol})$.

MBIC results demonstrated that, at the MBC for all three antimicrobials studied, there was less than $10 \%$ biofilm formed compared to the control. Additionally, at concentrations of antimicrobial agents equal to $1 / 2 \mathrm{MBC}(2 \mu \mathrm{g} / \mathrm{ml}$ for bicarinalin and BP100, $0.25 \mu \mathrm{g} / \mathrm{ml}$ for colistin) there was less inhibition of biofilm formation with $77 \%$ of biofilm formed in the presence of bicarinalin, 95\% in BP100 and 64\% in colistin. This highlights that even below their respective MBCs, bicarinalin and colistin have some potential to prevent biofilm formation but BP100 had very little, possibly due to differences in size and mechanism of action.

Biofilm eradication results indicated that bicarinalin is superior at eradicating $A$. baumannii biofilms than colistin above its $\mathrm{MBC}$ and both bicarinalin and BP100 are more effective at concentrations above $128 \mu \mathrm{g} / \mathrm{ml}$. Colistin was more effective at removing A. baumannii biofilms at low concentrations; this was as expected due to its lower $\mathrm{MBC}$ which is nearly an order of magnitude less than bicarinalin and BP100. However, the maximum biofilm removed was only $\sim 50 \%$ at $512 \mu \mathrm{g} / \mathrm{ml}$. Bicarinalin was the most effective between $8 \mu \mathrm{g} / \mathrm{ml}$, where it removed $\sim 40 \%$ of the biofilm, and $128 \mu \mathrm{g} / \mathrm{ml}$, where it eradicated $70 \%$ of the biofilm. Any further increase of concentration had no additional significant effect on the biofilm. The removal activity of BP100 started slowly and at $16 \mu \mathrm{g} / \mathrm{ml}$ it had removed only $20 \%$ of the biofilm, half that of colistin. Above $16 \mu \mathrm{g} / \mathrm{ml}$, BP100 increased relatively linearly to exceed bicarinalin activity above $512 \mu \mathrm{g} / \mathrm{ml}$. At $2048 \mu \mathrm{g} / \mathrm{ml}$, the highest concentration tested, BP100 had eradicated $\sim 95 \%$ of the biofilm. Colistin had the most biofilm removal activity, as expected, at low concentrations of $1-4 \mu \mathrm{g} / \mathrm{ml}$, below the MBC of bicarinalin and BP100. Bicarinalin was the most active between 8 and $128 \mu \mathrm{g} / \mathrm{ml}$ and BP100 was the most effective from 256 to $2048 \mu \mathrm{g} / \mathrm{ml}$. The superior performance of bicarinalin, and particularly that of BP100 on biofilms at higher concentrations, was not anticipated especially considering the $\mathrm{MBC}$ is significantly higher than colistin.

The SEM has been widely used to image bacterial biofilms [30,31], revealing, with increasing concentrations of peptide, progressive changes in cellular shape and structure of the biofilm. Membrane protrusions between bacterial cells were seen in the control sample 

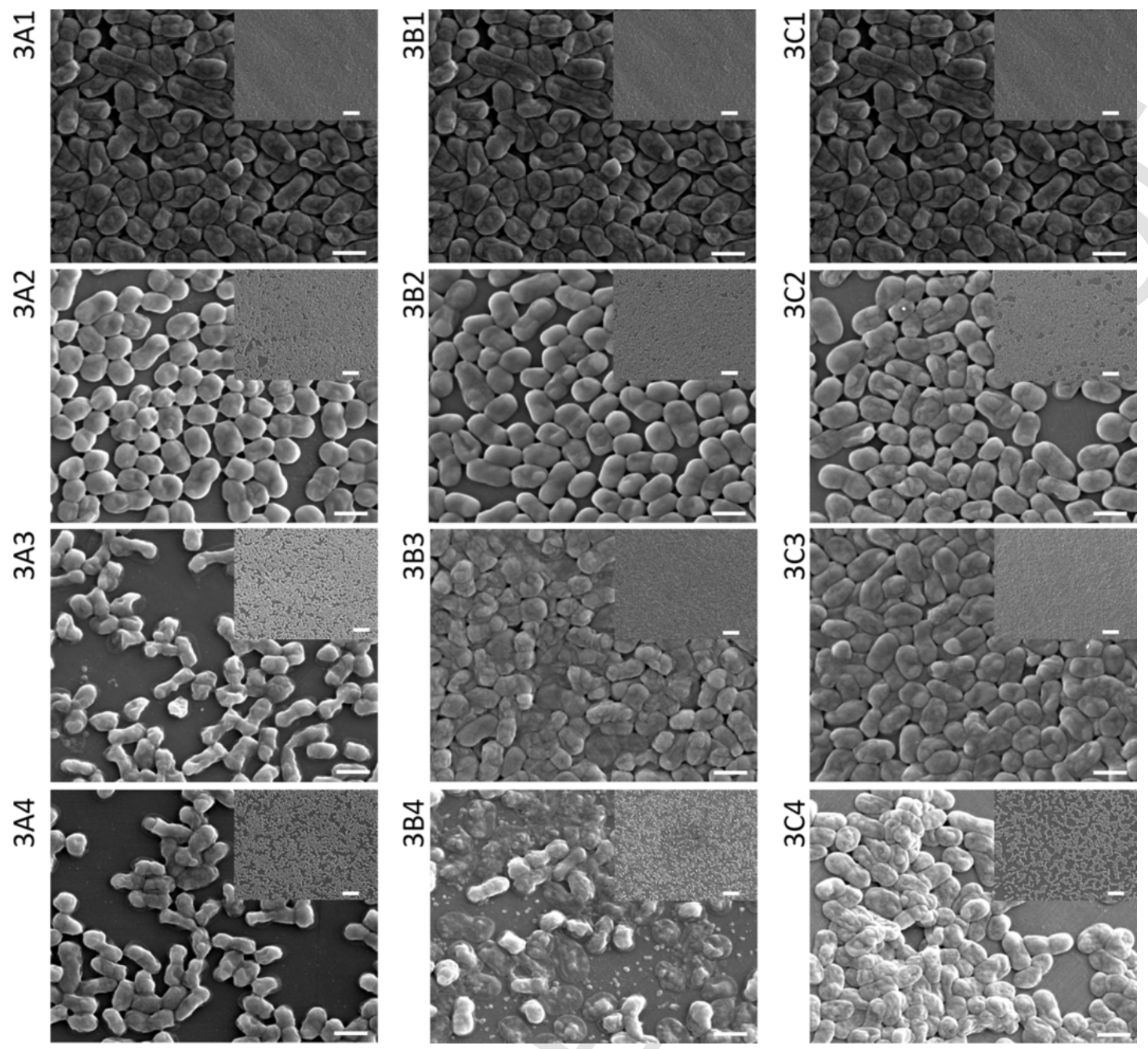

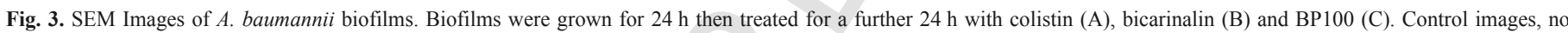
antimicrobial (1), $1 \mu \mathrm{g} / \mathrm{ml}(2), 10 \mu \mathrm{g} / \mathrm{ml}$ (3), $100 \mu \mathrm{g} / \mathrm{ml}$ (4). Scale bars on main images are $1 \mu \mathrm{m}, 10 \mu \mathrm{m}$ on inset images.

and at $1 \mu \mathrm{g} / \mathrm{ml}$ concentrations for each agent in this study. Pili or cellular filaments between cells have been previously documented between cells within biofilms [32,33]. At the higher concentrations of $10 \mu \mathrm{g} /$ $\mathrm{ml}$ and $100 \mu \mathrm{g} / \mathrm{ml}$, these protrusions were not visible suggesting the inability of the cells to form pili at these concentrations [34]. Fig. 3 clearly shows that as the concentration of agent is increased, the cell shape becomes less regular and the surface coverage is decreased.

The effect of the antimicrobials on $A$. baumannii was visualised by AFM. Fig. 4 highlights that, below the peptide MBC, the coccus-bacillus cell shape is conserved. However, at concentrations at and above the MBC, the cell surface, conformation and size are drastically affected. At the highest concentrations tested there is evidence of severe disruption to the cell surface, cytoplasmic leakage and lysed cells.

Membrane disruption caused by peptide activity is noted from various studies [20,35-37]. In this study, indentations and pores are seen in the bacterial surface with resulting cytoplasmic leakage and debris, suggesting loss of turgor pressure [38]. As the peptide concentration increased, more intense membrane perturbation and cytoplasmic leakage were visualised. Similar observations were described by Li et al. [35].
Although AFM imaging of bacterial cells in air is a widely used technique [20,39], it can lead to dehydration of the cell and changes in the cell surface that were not directly caused by peptide activity. However, all images have been compared to the control of untreated cells.

The dye leakage assay reflects the relative potency of these peptides against $A$. baumannii, suggesting that the peptides mediate their effects through the formation of pores in the membrane although it likely reflects planktonic growth more accurately than biofilm-like structures. It cannot be directly concluded whether the peptides exert their effects on the cytoplasmic or outer membrane of the cell. The visualised bacterial cell morphological changes seen in SEM (Fig. 3) and AFM (Fig. 4) images are likely to relate to outer membrane disorder while the vesicle leakage assay may represent disruption to the cytoplasmic membrane.

Overall the results support the proposal that bicarinalin and BP100 could be used to control infections caused by biofilm-producing prokaryotes. However, Torcato et al. [40] observed 50\% cytotoxicity against HELA cells at $49.2 \pm 1.4 \mu \mathrm{mol} / \mathrm{L}$ for BP100 which is higher than the MBC observed here $(2.8 \mu \mathrm{mol} / \mathrm{L})$ but lower than the concentrations needed for antibiofilm activity, suggesting that clinical antibiofilm activity of BP100 may be unlikely. Colistin performs well against planktonic cells of $A$. baumannii but significantly less well 

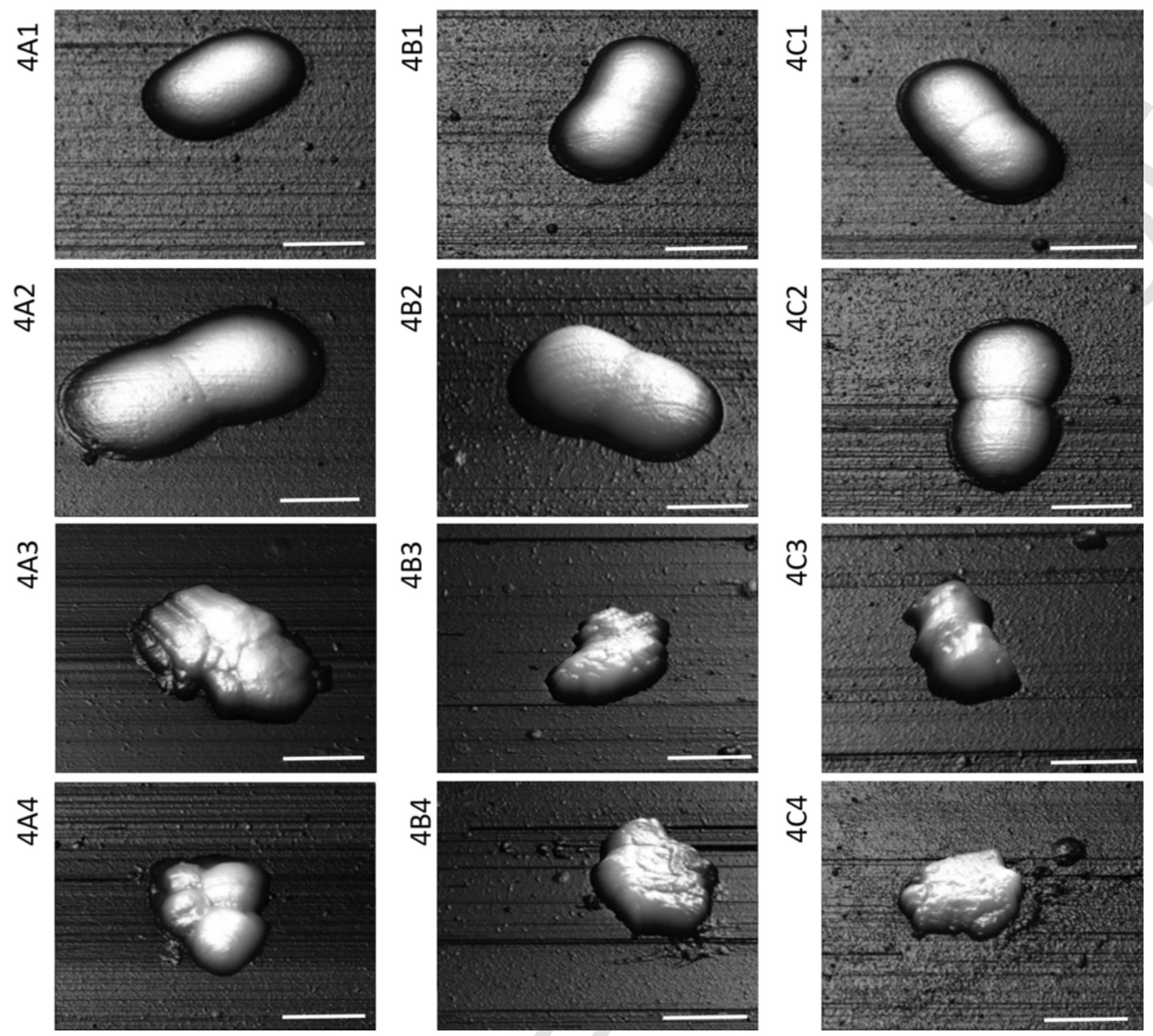

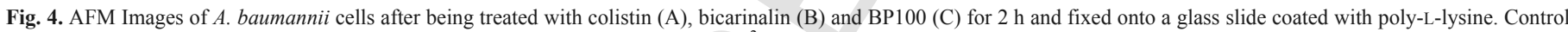
images, no antimicrobial (1), 1/2 MBC (2), MBC (3), $2 \times \mathrm{MBC}(4)$. Images were $4 \mu \mathrm{m}^{2}$ and 256 lines at $0.5 \mathrm{~Hz}$. Scale bars are $1 \mu \mathrm{m}$.

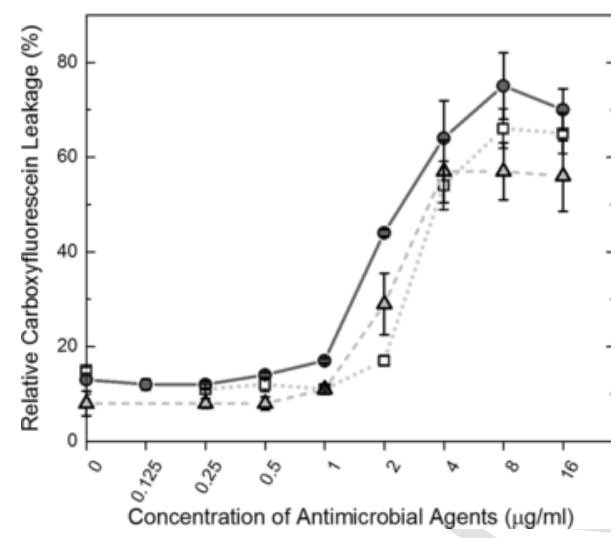

Fig. 5. The relative leakage of carboxyfluorescein from liposomes made from $A$. baumannii total lipid extract in the presence of increasing concentrations of the three antimicrobial agents. Error bars show the standard error around the mean of 3 replicates.

against biofilms. As A. baumannii is able to form biofilms, it is essential that investigations into the efficacy of novel agents are performed rigorously on biofilms.

The results indicate that bicarinalin and BP100 both have similar bactericidal and generally better anti-biofilm activity against $\mathrm{A}$. bau- mannii than colistin, with evidence supporting the idea that these peptides mediate their effects through the formation of pores in the membrane. This is encouraging but cytotoxic studies will determine whether, at these concentrations, bicarinalin and BP100 can be used in clinical treatment.

\section{Conflict of interest}

There is no conflict of interest between any author and any other people or organisation that could inappropriately influence this work.

\section{Acknowledgements}

The authors acknowledge Dr Richard Walshaw, Leeds Electron Microscopy \& Spectroscopy Centre for his support in the collection of the SEM images. This work was supported by the School of Life Sciences, University of Lincoln, UK. The study was approved by the College of Science Research Ethics Committee, University of Lincoln, UK.

\section{References}

[1] J. O'Neill, Tackling drug-resistant infections globally: final report and recommendations. The review on antimicrobial reistance, 2016. 
[2] J.S. Ward, et al., Toxicity of tryptophan manganese(i) carbonyl (Trypto-CORM) against Neisseria gonorrhoeae, MedChemComm 8 (2) (2017) 346-352.

[3] L.L. Ling, et al., A new antibiotic kills pathogens without detectable resistance, Nature 517 (7535) (2015) 455-459.

[4] M.S. Butler, M.A. Blaskovich, M.A. Cooper, Antibiotics in the clinical pipeline in 2013, J Antibiot 66 (10) (2013) 571-591.

[5] H. Giamarellou, A. Antoniadou, K. Kanellakopoulou, Acinetobacter baumannii: a universal threat to public health?, Int J Antimicrob Agents 32 (2) (2008) 106-119.

[6] I. Abbott, et al., Carbapenem resistance in Acinetobacter baumannii: laboratory challenges, mechanistic insights and therapeutic strategies, Expert Rev Anti Infect Ther 11 (4) (2013) 395-409.

[7] L.C.S. Antunes, P. Visca, K.J. Towner, Acinetobacter baumannii: evolution of a global pathogen, Pathogens and Disease 71 (3) (2014) 292-301.

[8] H.W. Boucher, et al., Bad bugs, No drugs: No ESKAPE! An Update from the infectious diseases Society of America, Clin Infect Dis 48 (1) (2009) 1-12.

[9] G.M. Eliopoulos, L.L. Maragakis, T.M. Perl, Acinetobacter baumannii: epidemiology, antimicrobial resistance, and treatment options, Clin Infect Dis 46 (8) (2008) 1254-1263.

[10] N. Høiby, et al., Antibiotic resistance of bacterial biofilms, Int J Antimicr Agents 35 (4) (2010) 322-332.

[11] P.S. Stewart, J. William Costerton, Antibiotic resistance of bacteria in biofilms, Lancet 358 (9276) (2001) 135-138.

[12] J.K. Schmier, C. H.-L, J.A. Klenk, K.A. Sulham, Economic burden and healthcare resource utilization associated with multi-drug resistant acinetobacter baumannii: a structured review of the literature, J Pharma Care Health Sys 3 (2) (2016).

[13] D.E. Karageorgopoulos, M.E. Falagas, Current control and treatment of multidrug-resistant Acinetobacter baumannii infections, Lancet Infect Dis 8 (12) (2008) 751-762.

[14] K.D. Roberts, et al., Antimicrobial activity and toxicity of the major lipopeptide components of polymyxin B and colistin: last-line antibiotics against multidrug-resistant gram-negative bacteria, ACS Infect Dis 1 (11) (2015) 568-575.

[15] E. Durante-Mangoni, et al., Emergence of colistin resistance without loss of fitness and virulence after prolonged colistin administration in a patient with extensively drug-resistant Acinetobacter baumannii, Diagn Microbiol Infect Dis 82 (3) (2015) 222-226

[16] A. Potron, L. Poirel, P. Nordmann, Emerging broad-spectrum resistance in Pseudomonas aeruginosa and acinetobacter baumannii: mechanisms and epidemiology, Int J Antimicrob Agents 45 (6) (2015) 568-585.

[17] M. Petrillo, A. Angers-Loustau, J. Kreysa, Possible genetic events producing colistin resistance gene $<\mathrm{em}>\mathrm{mcr}-1</ \mathrm{em}>$, Lancet Infect Dis 16 (3) (2016) 280.

[18] A. Rifflet, et al., Identification and characterization of a novel antimicrobial peptide from the venom of the ant Tetramorium bicarinatum, Peptides 38 (2) (2012) $363-370$.

[19] N. Téné, et al., Potent bactericidal effects of bicarinalin against strains of the Enterobacter and Cronobacter genera, Food Contr 42 (2014) 202-206.

[20] C.S. Alves, et al., Escherichia coli cell surface perturbation and disruption induced by antimicrobial peptides BP100 and pepR, J Biol Chem 285 (36) (2010) 27536-27544.

[21] E. Badosa, et al., A library of linear undecapeptides with bactericidal activity against phytopathogenic bacteria, Peptides 28 (12) (2007) 2276-2285.

[22] R. Ferre, et al., Synergistic effects of the membrane actions of cecropin-melittin antimicrobial hybrid peptide BP100, Biophys J 96 (5) (2009) 1815-1827.
[23] K.K. Hou, et al., A role for peptides in overcoming endosomal entrapment in siRNA delivery - a focus on melittin, Biotechnol Adv 33 (6, Part 1) (2015) 931-940.

[24] M.R. Yeaman, N.Y. Yount, Mechanisms of antimicrobial peptide action and resistance, Pharmacol Rev 55 (1) (2003) 27-55.

[25] T. Pott, et al., Melittin modifies bending elasticity in an unexpected way, Chem Phys Lipids 185 (2015) 99-108.

[26] M.C. Manzini, et al., Peptide:lipid ratio and membrane surface charge determine the mechanism of action of the antimicrobial peptide BP100. Conformational and functional studies, Biochimica et Biophysica Acta (BBA) - Biomembranes 1838 (7) (2014) 1985-1999.

[27] E.G. Bligh, W.J. Dyer, A Rapid Method of total lipid extraction and purification, Can J Biochem Physiol 37 (8) (1959) 911-917.

[28] J. Li, et al., Heteroresistance to colistin in multidrug-resistant acinetobacter baumannii, Antimicrob Agents Chemother 50 (9) (2006) 2946-2950.

[29] J.M. Saugar, et al., Activity of cecropin a-melittin hybrid peptides against colistin-resistant clinical strains of acinetobacter baumannii: molecular basis for the differential mechanisms of action, Antimicrob Agents Chemother 50 (4) (2006) 1251-1256.

[30] M. Alhede, et al., Combination of microscopic techniques reveals a comprehensive visual impression of biofilm structure and composition, FEMS Immunol Med Microbiol 65 (2) (2012) 335-342.

[31] R. Djeribi, et al., Characterization of bacterial biofilms formed on urinary catheters, Am J Infect Contr 40 (9) (2012) 854-859.

[32] J.A. Gaddy, et al., Role of acinetobactin-mediated iron acquisition Functions in the Interaction of Acinetobacter baumannii strain ATCC 19606(t) with human lung epithelial cells, Galleria mellonella caterpillars, and mice, Infect Immun 80 (3) (2012) 1015-1024

[33] N. Eaktasang, et al., Enhanced current production by electroactive biofilm of sulfate-reducing bacteria in the microbial fuel cell, Environ Engin Res 18 (4) (2013) 277-281.

[34] F. Longo, V. Claudio, G. Donelli, Biofilm formation in Acinetobacter baumannii, N Microbiol 37 (2014) 119-127.

[35] A. Li, et al., Atomic force microscopy study of the antimicrobial action of Sushi peptides on Gram negative bacteria, Biochimica et Biophysica Acta (BBA) Biomembranes 1768 (3) (2007) 411-418.

[36] P.C. Braga, D. Ricci, Atomic force microscopy: application to investigation of Escherichia coli morphology before and after exposure to cefodizime, Antimicrob Agents Chemother 42 (1) (1998) 18-22.

[37] R.L. Soon, et al., Effect of colistin exposure and growth phase on the surface properties of live Acinetobacter baumannii cells examined by atomic force microscopy, Int J Antimicrob Agents 38 (6) (2011) 493-501.

[38] M.N. Dickson, et al., Nanopatterned polymer surfaces with bactericidal proper ties, Biointerphases 10 (2) (2015) 021010.

[39] H.K. Webb, et al., Physico-mechanical characterisation of cells using atomic force microscopy - current research and methodologies, J Microbiol Meth 86 (2) (2011) 131-139.

[40] I.M. Torcato, et al., Design and characterization of novel antimicrobial peptides, R-BP100 and RW-BP100, with activity against Gram-negative and Gram-positive bacteria, Biochimica et Biophysica Acta (BBA) - Biomembranes 1828 (3) (2013) 944-955. 